\title{
Cocoa shell substrate, indolebutyric acid doses and length of cuttings in the rooting of Fridericia chica ${ }^{1}$
}

\author{
Viviane Maria Barazetti ${ }^{2}$,George Andrade Sodré ${ }^{3}$, \\ Eliandro Malta Rodrigues ${ }^{2}$, Eduardo Gross ${ }^{2}$
}

\section{ABSTRACT}

Fridericia chica (Bonpl.) L. G. Lohmann has medicinal properties and potential for commercial cultivation; however, the propagation characteristics of this species have been poorly evaluated. This study aimed to analyze the length of cuttings, indolebutyric acid (IBA) doses and substrates containing different proportions of cocoa shell in F. chica cuttings. Two experiments were carried out. In the first one, the treatments were basal cuttings of $10 \mathrm{~cm}$ and $20 \mathrm{~cm}$ in length and four IBA concentrations ( $0 \mathrm{mg} \mathrm{L}^{-1}, 2,000 \mathrm{mg} \mathrm{L}^{-1}, 4,000 \mathrm{mg} \mathrm{L}^{-1}$ and $\left.6,000 \mathrm{mg} \mathrm{L}^{-1}\right)$. In the second experiment, substrates obtained from five proportions of cocoa shell (CS) and expanded vermiculite (EV) compost were tested: $100 \% \mathrm{CS} ; 100 \% \mathrm{EV} ; 50 \% \mathrm{CS}+$ $50 \% \mathrm{EV} ; 30 \% \mathrm{CS}+70 \% \mathrm{EV} ; 70 \% \mathrm{CS}+30 \% \mathrm{EV}$. The rooting percentage, sprouting height and dry biomass production were evaluated. The production of $F$. chica seedlings can be performed by basal cuttings with $20 \mathrm{~cm}$ in length, which allow achieving a rooting rate of $91 \%$. The ideal IBA dose to obtain a maximum sprout length is 3,600 $\mathrm{mg} \mathrm{L}^{-1}$. Mixtures composed of $50 \% \mathrm{CS}+$ $50 \% \mathrm{EV}$ and $30 \% \mathrm{CS}+70 \% \mathrm{EV}$ were the best substrates for the production of $F$. chica seedlings.

KEYWORDS: Fridericia chica (Bonpl.) L. G. Lohmann, cocoa compost, medicinal plants.

\section{INTRODUCTION}

Fridericia chica (Bonpl.) L. G. Lohmann, originally from the Amazon region (Pauletti et al. 2003) and popularly known as "crajiru", "carajiru", "chica" or "pariri", is a shrub and climbing liana with bi or trifoliolate leaves and pink or violet flowers arranged in pyramidal panicles.

The species is used in folk medicine as an anti-inflammatory, healing and anti-anemic agent, as well as for the treatment of intestinal colic, hemorrhage, diarrhea and leukemia (Behrens et

\section{RESUMO}

Substrato de casca de cacau, doses de ácido indolbutírico e tamanho de estacas no enraizamento de Fridericia chica

Fridericia chica (Bonpl.) L. G. Lohmann apresenta propriedades medicinais e potencial para cultivo comercial; entretanto, as características de propagação dessa espécie são pouco estudadas. Objetivou-se avaliar o tamanho da estaca, doses de ácido indolbutírico (AIB) e substratos contendo diferentes proporções de casca de cacau, na estaquia de $F$. chica. Foram realizados dois experimentos. No primeiro, os tratamentos foram estacas basais de $10 \mathrm{~cm}$ e $20 \mathrm{~cm}$ de comprimento e quatro concentrações de $\operatorname{AIB}\left(0 \mathrm{mg} \mathrm{L}^{-1}, 2.000 \mathrm{mg} \mathrm{L}^{-1}\right.$, $4.000 \mathrm{mg} \mathrm{L}^{-1}$ e $6.000 \mathrm{mg} \mathrm{L}^{-1}$ ). No segundo, foram testados substratos obtidos de cinco proporções de compostagem de casca de cacau (CC) e vermiculita expandida (VE): $100 \% \mathrm{CC} ; 100 \% \mathrm{VE} ; 50 \% \mathrm{CC}+$ $50 \%$ VE; $30 \%$ CC $+70 \%$ VE; e $70 \%$ CC $+30 \%$ VE. Avaliaramse o percentual de enraizamento, altura da brotação e produção de biomassa seca. A produção de mudas de $F$. chica pode ser realizada por estacas basais com $20 \mathrm{~cm}$ de comprimento, que permitem alcançar $91 \%$ de enraizamento. A dose ideal de AIB para obter o máximo comprimento de broto é $3.600 \mathrm{mg} \mathrm{L}^{-1}$. As misturas de $50 \% \mathrm{CC}+$ $50 \% \mathrm{VE}$ e $30 \% \mathrm{CC}+70 \% \mathrm{VE}$ foram os melhores substratos para a produção de mudas da espécie.

PALAVRAS-CHAVES: Fridericia chica (Bonpl.) L. G. Lohmann, compostagem de cacau, plantas medicinais.

al. 2013). Ferreira et al. (2013) carried out the chemical characterization of $F$. chica leaf extract and evaluated its antimicrobial activity against Salmonella typhimurium, Lactobacillus acidophilus, Escherichia coli and Shigella sonnei bacteria, and the results showed that the classes of secondary metabolites (triterpenes, steroids, saponins, tannins, phenols and flavonoids) identified in the leaves of this species have medicinal potential, mainly as anti-inflammatory, antimicrobial and healing agents.

Despite being a species with a great therapeutic value, $F$. chica has not yet been commercially

1. Received: Aug. 27, 2019. Accepted: May 06, 2020. Published: June 24, 2020. DOI: 10.1590/1983-40632020v5060122.

2. Universidade Estadual de Santa Cruz, Ilhéus, BA, Brasil.E-mail/ORCID: barazetti.barazetti@gmail.com/ 0000-0001-8637-9207, agronomomalta@gmail.com/0000-0002-4503-017X, egross@uesc.br/0000-0002-1057-0432.

3. Comissão Executiva do Plano da Lavoura Cacaueira, Ilhéus, BA, Brasil.E-mail/ORCID: gasodre@hotmail.com/ 0000-0003-0711-8637. 
exploited, being found only in the wild or cultivated in domestic yards (Mendes 2008). Thus, the adequacy of propagation techniques may help in the species domestication by promoting the production of quality seedlings to be used in production systems, thus reducing its extractive production (Lusa \& Biasi 2011). Among the vegetative propagation methods, cuttings aim to obtain uniform seedlings, maintaining the characteristics of the mother plant and contributing to an increased yield (Mendes et al. 2014). In addition, cutting is a simple, fast and economically viable technique (Amaro et al. 2013).

Some medicinal species face difficulties in the rooting of cuttings, caused by internal factors such as mother plant physiology, genetic potential for rooting and hormonal balance, or external factors such as temperature, light, humidity and substrates (Mendes et al. 2014). Growth regulators have the function of inducing the formation of roots, increasing the percentage of rooted cuttings, number and quality of formed roots and rooting uniformity (Paulus et al. 2016).

Indolbutyric acid (IBA) is one of the most efficient auxins for promoting rooting in cuttings. Auxins stimulate the proliferation of various types of cells, such as formation of adventitious roots in cuttings, in addition to their main action, which is the initiation of root beginnings. IBA, as a synthetic auxin, has favorable characteristics, such as photostabilization, localized action, persistence, nontoxicity and resistance to biological action (Miranda et al. 2004).

Some studies have shown that the length of cuttings influences rooting, and this relationship may be related to the greater emission of sprouts in larger cuttings, which may have greater nutritional reserves, number of sprouts and contents of carbohydrates and endogenous auxins. Among these variables, the carbohydrate content is considered the main one, as it is a carbon source for the biosynthesis of nucleic acids and proteins used in the production of roots, in addition to increasing the $\mathrm{C} / \mathrm{N}$ ratio, which increases the rooting rate (Paulus et al. 2014, Hossel et al. 2017).

Another important factor for the vegetative propagation of plants is the selection of substrates. In the production of seedlings, substrates should be homogeneous, free of pathogens, have a low density, high porosity and adequate drainage. These characteristics should allow a good supply of water and oxygen, since $\mathrm{O}_{2}$ deficiency causes root growth to stop. This is not normally found in a single component, what leads to the use of mixtures of materials to obtain a better substrate (Wendling \& Gatto 2002, Bitencourt et al. 2010, Mendes et al. 2014).

Different raw materials of mineral and organic origin can be used, pure or in mixtures, to compose substrates for seedlings, such as carbonized rice husk, sawdust, peat, vermiculite and organic compost. When preparing substrate mixtures, it is important that the inputs used be of low cost and easy availability in the region, what favors their acquisition by nurserymen/farmers (Sodré et al. 2007, ArrigoniBlank et al. 2013).

Vermiculite is one of the most suitable raw materials for rooting herbaceous and semi-woody cuttings, due to its high porosity and good moisture retention (0.4-0.5 $\mathrm{m}^{3} \mathrm{~m}^{-3}$ ) (Martins et al. 2011), with a small variation in chemical and physical characteristics and high availability (Hartmann et al. 2011).

According to Fermino et al. (2010), the use of agro-industry residues, regionally available as a component for substrates, may reduce costs and minimize pollution, due to the accumulation of these materials in the environment. In this context, the cocoa agribusiness in the southern region of the Bahia state generates large amounts of shell, originating from fruit breaking for the extraction of almonds in the manufacture of chocolate. This residue, in general, remains in the soil in the so-called "casqueiros" and, according to Sodré et al. (2012), for the production of one ton of dried almonds, seven tons of fresh cocoa shell are produced. Cocoa shell contains about $4 \%$ of K on a dry basis (Sodré et al. 2012) and can have several uses, such as animal feeding (Abiola \& Tewe 1991), pectin extraction (Berbert 1972) and composting for the production of organic fertilizers (Chepote 2003).

This study aimed to evaluate the effect of IBA concentrations and substrates with proportions of cocoa shell and vermiculite on the rooting of F. chica cuttings.

\section{MATERIAL AND METHODS}

Two experiments were conducted in a greenhouse at the Comissão Executiva do Plano da Lavoura Cacaueira, in Ilhéus, Bahia state, Brazil, 
from February to August 2017. The herbaceous F. chica cuttings used in both experiments were collected from 10 juvenile mother plants, propagated via cuttings, with approximately two years of age and grown in 10-L pots filled with Carolina ${ }^{\circledR}$ commercial substrate.

In the first experiment, the effects of the length of two basal cuttings $(10 \mathrm{~cm}$ and $20 \mathrm{~cm})$ and four IBA concentrations $\left(0 \mathrm{mg} \mathrm{L}^{-1}, 2,000 \mathrm{mg} \mathrm{L}^{-1}, 4,000 \mathrm{mg} \mathrm{L}^{-1}\right.$ and $\left.6,000 \mathrm{mg} \mathrm{L}^{-1}\right)$ were evaluated. The experiment was conducted in a completely randomized design, in a $2 \times 4$ factorial scheme, with 10 replicates and experimental unit formed by three cuttings.

The cuttings were prepared by removing the leaves. Then, the base of the cuttings was immersed for 10 seconds in a 1:1 (v:v) hydroalcoholic IBA solution and placed to root in $120 \mathrm{~cm}^{3}$ tubes filled with Carolina ${ }^{\circledR}$ commercial substrate formulated with pine shell, peat and vermiculite at a 1:1:1 (v:v) ratio and maintained in an automated nebulization chamber programmed with 10 -second nebulization every 5 minutes, between 06:00 am and 06:00 pm, for 60 days.

For the second experiment, the compound obtained from the process of composting cocoa shell was tested, combined with vermiculite, as substrates for $F$. chica cuttings. The combinations were: $100 \%$ of cocoa shell; $100 \%$ of expanded vermiculite; $50 \%$ of cocoa shell $+50 \%$ of expanded vermiculite; $30 \%$ of cocoa shell $+70 \%$ of expanded vermiculite and $70 \%$ of cocoa shell $+30 \%$ of expanded vermiculite. A completely randomized design, with 10 replicates and three cuttings per experimental unit, was adopted.

The cocoa shell was obtained according to Sodré et al. (2012), with a metal chipper knife driven by an electric motor, sizing the pieces in $2.0 \mathrm{~cm}$ and arranging them in a pile $(2.5 \mathrm{~m}$ in length, $1.5 \mathrm{~m}$ in width and $1.0 \mathrm{~m}$ in height), under canvas polyethylene. Homogenization was carried out every eight days, until the mass temperature stabilized between $28{ }^{\circ} \mathrm{C}$ and $30^{\circ} \mathrm{C}$, what occurred at 90 days, when the material was then considered stabilized. After homogenization, chemical ( $\mathrm{pH}$ and electrical conductivity) and physical (water holding capacity, density and humidity) analyses were performed. Density and humidity were determined according to Zorzeto et al. (2014); water holding capacity was performed according to Kiehl (1979), without vibration; and the $\mathrm{pH}$ and electrical conductivity were evaluated with the aid of $\mathrm{pH}$ and semi-solid electrical conductivity probes, respectively. It is noteworthy that, even considering differences in the chemical characteristics among the substrates, nutrients were not added before or during the rooting period.

Basal cuttings of $20 \mathrm{~cm}$ in length without leaves treated with IBA at a dose of $2,000 \mathrm{mg} \mathrm{L}^{-1}$ were used. This dose refers to the maximum economic efficiency obtained from $55 \%$ of the maximum value found in the first derivative of the regression equation that described the behavior of the sprout length, as a function of IBA doses, found in the first experiment. Cuttings were inserted in tubes containing $120 \mathrm{~cm}^{3}$ of the substrate that composed the treatments and transferred to the automated nebulization chamber.

In both experiments, the following variables were evaluated: rooting; number of plants with expanded roots and leaves (expressed as percentage); number of sprouts; sprout length; measure of the sprout insertion in the cutting to the apex; main root length; dry shoot biomass; dry root biomass; and total dry biomass, by weighing the sprout and root plant material.

Data were submitted to analysis of variance ( $F$ test) and then means were compared by the Tukey test at $5 \%$ of probability for qualitative analyses and regression for quantitative analyses. The percentage data was transformed into $\arcsin \sqrt{ } \mathrm{x} / 100$.

\section{RESULTS AND DISCUSSION}

In the first experiment, which evaluated the length of cuttings and IBA doses, a significant interaction between the factors was observed only for the variable sprout length. The largest shoot length $(16.5 \mathrm{~cm})$ was found at an IBA dose of $3,600 \mathrm{mg} \mathrm{L}^{-1}$ for the 20-cm cutting (Figure 1); while, for the 10-cm cutting, no significant adjustment for the IBA doses was performed.

Significant differences were observed for the length of cuttings for rooting and number of sprouts. The rooting percentage was significantly higher for the $20-\mathrm{cm}$ cuttings, when compared to the $10-\mathrm{cm}$ ones (Table 1), which presented $91 \%$ of rooting and a higher number of sprouts (4.7 sprouts cut $\left.{ }^{-1}\right)$. According to Hartmann et al. (2011), this effect may be explained by the fact that, in general, cuttings of a greater length have a greater amount of reserves, and that the formation of new structures in the shoots of cuttings acts as a drain on the reserves of carbohydrates and nitrogen compounds. 


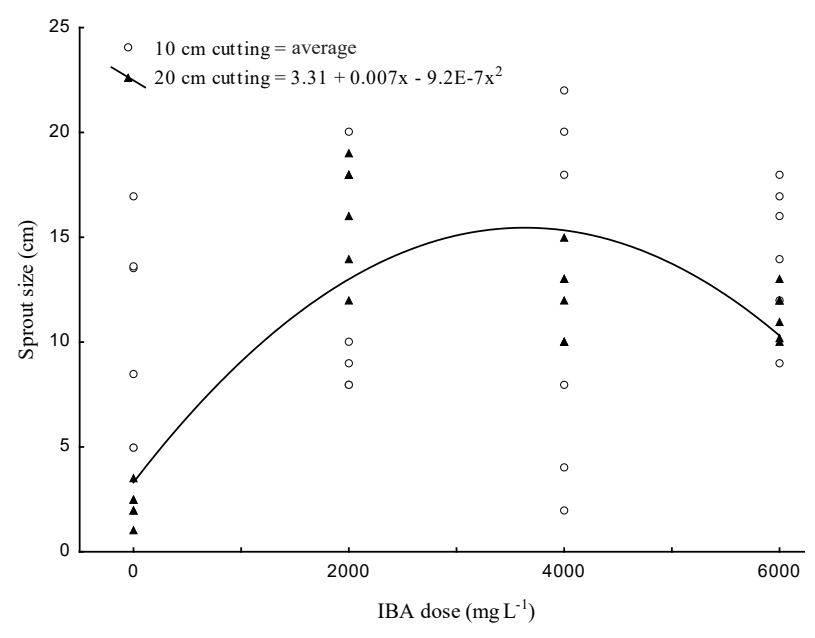

Figure 1. Shoot length of Fridericia chica cuttings at 60 days after staking $(\mathrm{n}=10)$, as a function of indolebutyric acid (IBA) doses and length of cuttings.

Table 1. Rooting of cuttings, number of sprouts per cutting and length of the largest root, according to the length used in the Fridericia chica cuttings.

\begin{tabular}{lccc}
\hline $\begin{array}{c}\text { Length of } \\
\text { cuttings }\end{array}$ & $\begin{array}{c}\text { Rooting } \\
(\%)\end{array}$ & $\begin{array}{c}\text { Number of } \\
\text { sprouts }\end{array}$ & $\begin{array}{c}\text { Root Length } \\
(\mathrm{cm})\end{array}$ \\
\hline $10 \mathrm{~cm}$ & $84.00 \mathrm{~b}^{*}$ & $2.80 \mathrm{~b}$ & $11.00 \mathrm{a}$ \\
$20 \mathrm{~cm}$ & $91.00 \mathrm{a}$ & $4.70 \mathrm{a}$ & $12.00 \mathrm{a}$ \\
\hline $\mathrm{CV}(\%)$ & 11.75 & 33.50 & 36.80 \\
\hline MSD & 0.19 & 0.74 & 1.82 \\
\hline
\end{tabular}

* Means followed by same letter in the column do not differ by the Tukey test at $5 \%$ of probability $(\mathrm{p} \leq 0.05)$.

For root length, no significant difference was observed between the treatments, but the $20-\mathrm{cm}$ cuttings showed a higher number of secondary roots. The greater root length and branching verified in the $20-\mathrm{cm}$ cuttings may be a consequence of greater amounts of nutrient reserves, which can be translocated to the plant base and assist in the root formation (Hartmann et al. 2011). The presence of greater amounts of roots also implies an increase in the soil area explored for the absorption of water and nutrients, which consequently may result in a greater plant growth in the field (Paulus et al. 2016).

For total dry biomass, the regression model was adjusted between IBA doses with significant effect for 20 -cm cuttings. As IBA doses increase, there is an increase in the total dry biomass (Figure 2). Rooting studies generally recommend the use of exogenous auxins in cuttings, as they promote hormonal changes, favoring rooting and increasing root biomass

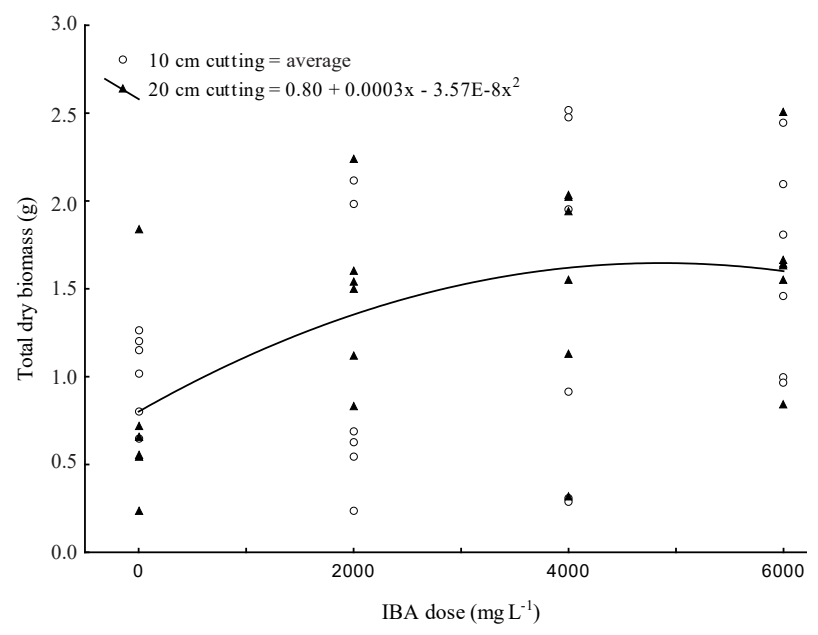

Figure 2. Total dry biomass of $10-\mathrm{cm}$ and $20-\mathrm{cm}$ cuttings of Fridericia chica at 60 days after staking $(\mathrm{n}=10)$, as a function of indolebutyric acid doses and cutting length.

(Fachinello et al. 2005, Dutra et al. 2012, Pereira et al. 2018). Dias et al. (2015) observed, in Schizolobium amazonicum cuttings, that the higher the IBA concentrations, the greater is the dry root biomass, while Paulus et al. (2016) observed positive effects for the rooting of rosemary cuttings, in addition to growth in height and accumulation of fresh and dry mass of shoots and roots, thus making rooting more efficient, also observing that cuttings treated with high IBA doses showed a higher seedling quality, being more dense and well formed, a desirable characteristic when planting seedlings in the field. The results showed that the application of exogenous auxins to F. chica cuttings increased the growth, quality of the root system and rooting of cuttings.

Table 2 shows the values of the chemical and physical attributes of the substrates used in the F. chica cuttings. According to Carvalho (2015), the recommended $\mathrm{pH}$ for the cultivation of medicinal plants is between 6.0 and 6.5. In comparison with the values found and excluding the $30 \%$ of cocoa shell $+70 \%$ of expanded vermiculite substrate, it was observed that the $\mathrm{pH}$ is above the ideal range; however, it did not prevent the root formation, probably due to the short duration of the experiment (60 days).

Differences of up to three times the water holding capacity were observed among the substrates (Table 2). Very low water holding capacity values, such as those found in $100 \%$ of cocoa shell and $70 \%$ of cocoa shell $+30 \%$ of expanded vermiculite 
Table 2. $\mathrm{pH}$ values, electrical conductivity, water retention capacity, density and humidity of substrates used in the rooting of Fridericia chica, before the experiment was installed.

\begin{tabular}{lccccc}
\hline \multicolumn{1}{c}{ Substrates } & $\mathrm{pH}$ & $\begin{array}{c}\text { Electrical conductivity } \\
\left(\mu \mathrm{S} \mathrm{cm}^{-1}\right)\end{array}$ & $\begin{array}{c}\text { Water holding capacity } \\
\left(\mathrm{m}^{3} \mathrm{~m}^{-3}\right)\end{array}$ & $\begin{array}{c}\text { Density } \\
\left(\mathrm{g} \mathrm{cm}^{-3}\right)\end{array}$ & $\begin{array}{c}\text { Humidity } \\
(\%)\end{array}$ \\
\hline $100 \% \mathrm{CS}$ & 7.3 & 3.26 & 0.12 & 0.46 & 0.43 \\
$100 \% \mathrm{EV}$ & 6.7 & 0.01 & 0.34 & 0.16 & 0.04 \\
$50 \% \mathrm{CS}+50 \% \mathrm{EV}$ & 6.7 & 1.61 & 0.32 & 0.39 & 0.33 \\
$30 \% \mathrm{CS}+70 \% \mathrm{EV}$ & 6.3 & 0.29 & 0.35 & 0.26 & 0.17 \\
$70 \% \mathrm{CS}+30 \% \mathrm{EV}$ & 6.9 & 1.18 & 0.19 & 0.36 & 0.27 \\
\hline
\end{tabular}

$\mathrm{EV}=$ expanded vermiculite; $\mathrm{CS}=$ cocoa shell.

substrates, may cause a low water availability for plants (Fachinello et al. 2005). On the other hand, the substrate with $30 \%$ of cocoa shell $+70 \%$ of expanded vermiculite presented the highest water holding capacity $\left(0.35 \mathrm{~m}^{3} \mathrm{~m}^{-3}\right)$. The $\mathrm{pH}$ values found in the literature indicate a $\mathrm{pH}$ around 6.3 as ideal for the propagation of medicinal plants. It is noteworthy that high water holding capacity values mean a reduced space for aeration, reducing the oxygen content available for root development (Allaire et al. 2004).

There was an effect of substrates on all analyzed variables, and $50 \%$ of cocoa shell + $50 \%$ of expanded vermiculite substrate had higher rooting percentages $(95.2 \%)$ and a longer sprout length $(8.28 \mathrm{~cm})$, but did not differ from the $30 \%$ of cocoa shell $+70 \%$ of expanded vermiculite treatment (Table 3). This better performance may be attributed to the greater water holding capacity of vermiculite $\left(0.4-0.5 \mathrm{~m}^{3} \mathrm{~m}^{-3}\right)$, when compared to cocoa shell (Martinset al. 2011). In this experiment, vermiculite showed a water holding capacity of $0.34 \mathrm{~m}^{3} \mathrm{~m}^{-3}$ (Table 2), which probably favored the root development and consequently the shoot growth. Silva et al. (2015) worked with Lippia origanoides and found a greater root development and initial growth of seedlings in a treatment using Biomix ${ }^{\circledR}$ commercial substrate + vermiculite at a 1:1 ratio.
The $100 \%$ of cocoa shell substrate was inferior to the other substrates and, for root length, it differed significantly from the $100 \%$ of vermiculite and $30 \%$ of cocoa shell $+70 \%$ of expanded vermiculite substrates. This result possibly occurred because cuttings rooted in the $30 \%$ of cocoa shell $+70 \%$ of expanded vermiculite substrate had a root length and total dry biomass significantly different from the others, with averages of $14.5 \mathrm{~cm}$ and $0.72 \mathrm{~g}$, respectively (Table 3 ). These root length results may be, in principle, attributed to the high $\mathrm{K}$ concentration present in the shell, which increases the electrical conductivity (Sodré et al. 2012) in the cocoa shell. A high electrical conductivity in the substrate $\left(3.26 \mu \mathrm{s} \mathrm{cm}^{-1}\right)$ causes a reduction in the plant growth, affecting the availability, transport and partition of nutrients (Freitas et al. 2014). Additionally, the physical properties of the substrate explain why vermiculite is generally used as a substrate for rooting herbaceous and semi-hardwood cuttings of several species, and this is due to the high porosity and good moisture retention of vermiculite, highly desirable characteristics in the adventitious rooting process (Fachinello et al. 2005).

In general, the characteristics of the substrate influence the adventitious rooting of cuttings, because, in addition to the support function, they

Table 3. Rooting of cuttings, sprout length, main root length, dry shoot and root biomass and total dry biomass in the propagation of Fridericia chica with different substrates.

\begin{tabular}{|c|c|c|c|c|c|c|}
\hline Types of substrate & $\begin{array}{c}\text { Rooting } \\
\%\end{array}$ & $\begin{array}{l}\text { Sprout } \\
\text { length }\end{array}$ & $\begin{array}{l}\text { Root } \\
\text { length }\end{array}$ & $\begin{array}{c}\text { Dry shoot } \\
\text { biomass }\end{array}$ & $\begin{array}{c}\text { Dry root } \\
\text { biomass } \\
\mathrm{g} \\
\end{array}$ & $\begin{array}{l}\text { Total dry } \\
\text { biomass }\end{array}$ \\
\hline $100 \% \mathrm{CS}$ & $47.6 c^{*}$ & $4.28 \mathrm{ab}$ & $9.50 \mathrm{c}$ & $0.28 \mathrm{ab}$ & $0.12 \mathrm{~b}$ & $0.40 \mathrm{~b}$ \\
\hline $100 \% \mathrm{EV}$ & $81.0 \mathrm{ab}$ & $4.71 \mathrm{ab}$ & $12.50 \mathrm{ab}$ & $0.20 \mathrm{~b}$ & $0.21 \mathrm{ab}$ & $0.41 \mathrm{~b}$ \\
\hline $50 \% \mathrm{CS}+50 \% \mathrm{EV}$ & $95.2 \mathrm{a}$ & $8.28 \mathrm{a}$ & $11.71 \mathrm{bc}$ & $0.40 \mathrm{a}$ & $0.24 \mathrm{ab}$ & $0.64 \mathrm{ab}$ \\
\hline $30 \% \mathrm{CS}+70 \% \mathrm{EV}$ & $90.5 \mathrm{ab}$ & $7.14 \mathrm{a}$ & $14.50 \mathrm{a}$ & $0.43 \mathrm{a}$ & $0.29 \mathrm{a}$ & $0.72 \mathrm{a}$ \\
\hline $70 \% \mathrm{CS}+30 \% \mathrm{EV}$ & $71.4 \mathrm{bc}$ & $6.57 \mathrm{ab}$ & $11.30 \mathrm{bc}$ & $0.35 \mathrm{ab}$ & $0.20 \mathrm{ab}$ & $0.55 \mathrm{ab}$ \\
\hline
\end{tabular}

* Means followed by the same letter in the column do not differ by the Tukey test at $5 \%$ of probability $(\mathrm{p} \leq 0.05)$. EV $=$ expanded vermiculite; CS $=$ cocoa shell. 
also present characteristics of water, nutrient and oxygen supply, which favor the root growth (Timm et al. 2015, Almeida et al. 2017). It was also observed that the mixture of two or more materials, as used in this study to compose the mixtures of substrates, allows reaching intermediate water retention, aeration and availability levels, also favoring the rooting of cuttings (Pereira et al. 2012). Fachinello et al. (2005) and Timm et al. (2015) found that the effect of the substrate, both on the rooting percentage and on the quality of formed roots, is related to porosity, which affects the retained water content and, consequently, aeration. These authors also highlight that substrates with higher density values may represent a greater resistance to the expansion of plant roots.

The use of vermiculite combined with cocoa shell resulted in a higher rooting percentage, when compared to the $100 \%$ of cocoa shell and $70 \%$ of cocoa shell $+30 \%$ of expanded vermiculite substrates. Among the effects of vermiculite, the increase in the porosity of substrates stands out (Timm et al. 2015), and, according to Lima \& Rezende Filho (2016), the mixture of materials to compose substrates is recommended in the vegetative propagation, and the mixture of organic materials with vermiculite is desirable due to the availability and drainage, which provide a better rooting of cuttings.

The $30 \%$ of cocoa shell $+70 \%$ of expanded vermiculite substrate promoted a longer sprout and root length, being, consequently, a better response to the dry shoot and root biomass. It is possible that the greater amount of vermiculite and the consequent greater water retention in this substrate may have influenced this result. Similar results were obtained in Aristolochia triangular cuttings by Corrêa \& Biasi (2003), who observed that vermiculite provided a better aeration and root formation.

\section{CONCLUSIONS}

1. The production of Fridericia chica seedlings can be carried out by basal cuttings with $20 \mathrm{~cm}$ in length, which allow achieving rooting rates of up to $91 \%$;

2. The IBA dose for a maximum sprout length is $3,600 \mathrm{mg} \mathrm{L}^{-1}$

3. Mixtures of $50 \%$ of cocoa shell $+50 \%$ of expanded vermiculite and $30 \%$ of cocoa shell $+70 \%$ of expanded vermiculite were the best substrates for the production of seedlings of this species;
4. The adoption of vermiculite in the composition of the substrate improves the conditions for rooting and growth of seedlings;

5. Cocoa shell should not be used in isolation for the production of $F$. chica seedlings.

\section{ACKNOWLEDGMENTS}

The authors would like to thank the Coordenação de Aperfeiçoamento de Pessoal de Nível Superior (Capes Financing Code 001), for granting a scholarship to Viviane Maria Barazetti; and the Programa de Pós-Graduação em Produção Vegetal of the Universidade Estadual de Santa Cruz and Comissão Executiva do Plano da Lavoura Cacaueira (Ceplac), for the institutional support and facilities provided to carry out this study.

\section{REFERENCES}

ABIOLA, S. S.; TEWE, O. O. Chemical evaluation of cocoa by-products. Tropical Agriculture, v. 68, n. 4, p. 335-336, 1991.

ALLAIRE, S.; CARON, J.; MÉNARD, C.; DORAIS, M. Growing media varying in particle size and shape for greenhouse tomato. Acta Horticulturae, v. 644, n. 1, p. 307-311, 2004.

ALMEIDA, J. P. N.; LEITE, G. A.; MENDONÇA, V.; FREITAS, P. S. C.; ARRAIS, I. G.; TOSTA, M. S. Concentrações de AIB e substratos no enraizamento e vigor de estacas lenhosas de cajaraneira. Revista de Ciências Agrárias, v. 60, n. 1, p. 11-18, 2017.

AMARO, H. T. R.; SILVEIRA, J. R.; DAVID, A. M. S. de S.; RESENDE, M. A. V.; ANDRADE, J. A. S. Tipos de estacas e substratos na propagação vegetativa da menta (Mentha arvensis L.). Revista Brasileira de Plantas Medicinais, v. 15, n. 3, p. 313-318, 2013.

ARRIGONI-BLANK, M. de F.; BLANK, A. F.; SANTOS, T. C. Production of vetiver (Chrysopogon zizanioides (L.) Roberty) plantlets using different substrates. Bioscience Journal, v. 29, n. 3, p. 597-604, 2013.

BEHRENS, M. D.; TELLIS, C. J. M.; CHAGAS, M. do S. Arrabidaea chica (Humb. \& Bonpl.) B. Verlot (Bignoniaceae). Revista Fitos Eletrônica, v. 7, n. 4, p. 236244, 2013.

BERBERT, P. R. F. Estudo da pectina do mel e da casca do fruto de cacau. Revista Theobroma, v. 1, n. 1, p. 49-51, 1972.

BITENCOURT, J.; ZUFFELLATO-RIBAS, K. C.; KOEHLER, H. S. Ginkgo biloba L. cutting using three substrates. Revista Brasileira de Plantas Medicinais, v. 12, n. 2, p. 135-140, 2010. 
CARVALHO, L. M. Orientações técnicas para o cultivo de plantas medicinais, aromáticas e condimentares. Aracaju: Embrapa Tabuleiros Costeiros, 2015.

CORRÊA, C.; BIASI, L. Área foliar e tipo de substrato na propagação por estaquia de cipó-mil-homens (Aristolochia triangularis Cham. Et schl.). Current Agricultural Science and Technology, v. 9, n. 3, p. 233-235, 2003.

CHEPOTE, R. E. Efeito do composto da casca do fruto de cacau no crescimento e produção do cacaueiro. Agrotrópica, v. 15, n. 1, p. 1-8, 2003.

DIAS, P. C.; ATAÍDE, G. M.; XAVIER, A.; OLIVEIRA, L. S.; PAIVA, H. N. Propagação vegetativa de Schizolobium amazonicum por estaquia. Cerne, v. 21, n. 3, p. 379-386, 2015.

DUTRA, T. R.; GRAZZIOTTI, P. H.; SANTANA, R. C.; MASSAD, M. D. Desenvolvimento inicial de mudas de copaíba sob diferentes níveis de sombreamento e substratos. Revista Ciência Agronômica, v. 43, n. 2, p. 321-329, 2012.

FACHINELLO, J. C.; HOFFMANN, A.; NACHTIGAL, J. C. Propagação de plantas frutiferas. Brasília, DF: Embrapa Informação Tecnológica, 2005.

FERMINO, M. H.; GONÇALVES, R. S.; BATTISTIN, A.; SILVEIRA, J. R. P.; BUSNELLO, A. C.; TREVISAM, M.Reutilization of wastes from the production of palm heart canning as substrates for plants. Horticultura Brasileira, v. 28, n. 3, p. 282-286, 2010.

FERREIRA, F. A. G.; CARVALHO, C. M.; COSTA, J. C.; FERREIRA, J. M. R.; SILVA, F. Comprovação do potencial medicinal de Arrabidaea chica (Bignoniaceae). Scientia Prima, v. 1, n. 1, p. 1-6, 2013.

FREITAS, M. A. C.; AMORIM, A. V.; BEZERRA, A. M. E.; PEREIRA, M. S.; BESSA, M. C.; NOGUEIRA FILHO, F. P.; LACERDA, C. F. Crescimento e tolerância à salinidade em três espécies medicinais do gênero Plectranthus expostas a diferentes níveis de radiação. Revista Brasileira de Plantas Medicinais, v. 16, n. 4, p. 839-849, 2014.

HARTMANN, H. T.; KESTER, D. E.; DAVIES JUNIOR, F. T.; GENEVE, R. L. Hartmann \& Kester's plant propagation: principles and practices. 8 . ed. Boston: Pearson, 2011.

HOSSEL, C.; HOSSEL, J. S. A. O.; WAGNER JUNIOR, A. Tamanho de estaca e concentração de ácido indolbutírico na propagação do sabugueiro por estaquia. Revista Brasileira de Tecnologia Agropecuária, v. 1, n. 2, p. 109112, 2017.

KIEHL, E. J. Fertilizantes orgânicos. Piracicaba: Ceres, 1979.
LIMA, C. C.; REZENDE FILHO, A. Substrato no enraizamento de estacas provenientes de mudas de Schizolobium parahyba var. amazonicum. Enciclopédia Biosfera, v. 13, n. 23, p. 1270-1282, 2016.

LUSA, M. G.; BIASI, L. A. Cutting of Cuphea calophylla subsp. mesostemon (Koehne) Lourteig (Lythraceae). Revista Brasileira de Plantas Medicinais, v. 13, n. 1, p. 52-57, 2011.

MARTINS, C. C.; MACHADO, C. G.; CALDAS, I. G. R.; VIEIRA, I. G. Vermiculita como substrato para o teste de germinação de sementes de barbatimão. Ciência Florestal, v. 21, n. 3, p. 421-427, 2011.

MENDES, A. D. R.; LACERDA, T. H. S.; ROCHA, S. M. G.; MARTINS, E. R. Growth regulators and substrates on rooting of Varronia curassavica Jacq. Revista Brasileira de Plantas Medicinais, v. 16, n. 2, p. 262-270, 2014.

MENDES, R. Aspectos da produção agroecológica no baixo Acre. 2008. Dissertação (Mestrado em Produção Vegetal) - Universidade Federal do Acre, Rio Branco, 2008.

MIRANDA, C. S.; CHALFUN, N. N. J.; HOFFMANN, A.; DUTRA, L. F.; COELHO, G. V. A. Enxertia recíproca e AIB como fatores indutores do enraizamento de estacas lenhosas dos porta-enxertos de pessegueiro "Okinawa" $\mathrm{e}$ umezeiro. Ciência e Agrotecnologia, v. 28, n. 4, p. 778784, 2004.

PAULETTI, P. M.; BOLZANI, V. S.; YOUNG, M. C. Constituintes químicos de Arrabidaea samydoides (Bignoniaceae). Química Nova, v. 26, n. 5, p. 641-643, 2003.

PAULUS, D.; VALMORBIDA, R.; PAULUS, E. Ácido indolbutírico na propagação vegetativa de alecrim. Horticultura Brasileira, v. 34, n. 4, p. 520-528, 2016.

PAULUS, D.; VALMORBIDA, R.; TOFFOLI, E.; PAULUS, E. Vegetative propagation of Aloysia triphylla (L'Hér.) Britton according to IBA and length of cuttings. Revista Brasileira de Plantas Medicinais, v. 16, n. 1, p. 25-31, 2014.

PEREIRA, E. de O.; LOPES, J. C.; MARÇAL, T. S.; COELHO, R. I. Enraizamento de estacas de maracujazeiro cultivadas em diferentes substratos e tratadas com extratos de tiririca. Nucleus, v. 9, n. 2, p. 93-102, 2012.

PEREIRA, R. A.; GOMES JUNIOR, G. A.; SODRÉ, G. A.; SACRAMENTO, C. K. Doses e métodos de aplicação de ácido indolbutírico no enraizamento de miniestacas de cacaueiro. Magistra, v. 29, n. 3/4, p. 305-314, 2018.

SILVA, G. C.; OLIVEIRA, L. M.; LUCCHESE, A. M.; SILVA, T. R. S.; NASCIMENTO, M. N. Propagação vegetativa e crescimento inicial de Lippia origanoides 
(alecrim-de-tabuleiro). Horticultura Brasileira, v. 33, n. 2, p. 236-240, 2015.

SODRÉ, G. A.; CORÁ, J. E.; SOUZA JUNIOR, J. O. Physical characteristics of substrates of sawdust and containers to growth cuttings of cacao. Revista Brasileira de Fruticultura, v. 29, n. 2, p. 339-344, 2007.

SODRÉ, G. A.; VENTURINI, M. T.; RIBEIRO, D. O.; MARROCOS, P. C. L. Extrato da casca do fruto do cacaueiro como fertilizante potássico no crescimento de mudas de cacaueiro. Revista Brasileira Fruticultura, v. 34, n. 3, p. 881-887, 2012.
TIMM, C. R. F.; SCHUCH, M. W.; TOMAZ, Z. F. P.; MAYER, N. M. A. Enraizamento de miniestacas a partir de ramos herbáceos de porta-enxertos de pessegueiro, em diferentes substratos. Revista Inova Ciência \& Tecnologia, v. 1, n. 1, p. 18-22, 2015.

WENDLING, I.; GATTO, A. Substratos, adubação e irrigação na produção de mudas. Viçosa: Aprenda Fácil, 2002.

ZORZETO, T. Q.; DECHEN, S. C. F.; ABREU, M. F.; FERNANDES JUNIOR, F. Caracterização física de substratos para plantas. Bragantia, v. 73, n. 3, p. 300-311, 2014. 